Yavorska Viktoriia, Shynkarenko Sergii. Current challenges of forming socio-economic model of the city development. Journal of Education, Health and Sport. 2022;12(1):321-330. eISSN 2391-8306. DOI http://dx.doi.org/10.12775/JEHS.2022.12.01.027

https://apcz.umk.pl/JEHS/article/view/JEHS.2022.12.01.027

https://zenodo.org/record/5930936

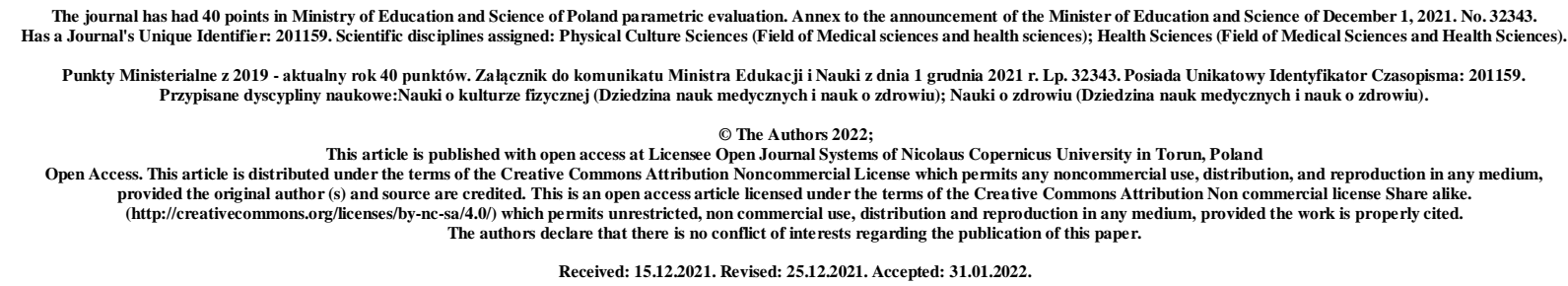

\title{
CURRENT CHALLENGES OF FORMING SOCIO-ECONOMIC MODEL OF THE CITY DEVELOPMENT
}

\author{
Viktoriia Yavorska, Sergii Shynkarenko
}

Odessa I. I. Mechnikov National University

\begin{abstract}
The article analyzed current challenges of forming the socio-economic model of city development in the forms of urbanization, its types, consequences, and structural changes in societies.

Keywords: urbanization; socio-economic model of the city development; intensive type of urbanization; extensive type of urbanization

The statement of the problem. In the modern world consciousness, issues related to various aspects of urban development are crucial in the progress of the current economy. Socioeconomic development at the macro level affects the demand for residential, industrial, and commercial locations. The availability of appropriate locations and the actual spatial configuration, in turn, affect overall socio-economic development. Currently, urbanization is one of the main challenges for society, which positively impacts economic growth. This complex socio-economic process changes the built environment, transforming former rural settlements
\end{abstract}


into urban ones. At the same time, this phenomenon is causing inequality worldwide, with some areas benefiting more from public investment and economic growth than others.

The urban environment in the context of urbanization of public life is undergoing significant transformational changes. That is why new forms and mechanisms of the management organization and further development should be elaborated to benefit the citizens themselves and other target groups. Ensuring the development of the urban environment is impossible without optimizing the design process, forming a socio-economic model, and implementing public policy in urban areas. Understanding the relationship between the physical characteristics of the urban environment and the socio-economic level of city residents is appropriate in forming a socioeconomic model of urban development.

The latest scientific progress and publications review. Various foreign scholars, namely R. Grant, N. Comninos, P. Lombardi, S. Marvin, P. Naes, R. Hollandes, R. Raven, D. Romero, R. Funk, and J. Friedman, considered the functioning of economic systems in the conditions of urban territories and agglomerations, processes of management of the urban environment and urban space from the socio-economic point of view.

Some authors, which can be attributed either to the supporters of the compact pedestrian form of the city or to the more developed and focused on the automotive urban environment of the city, used qualitative methods based on observation or personal views. Thus, Jacobs (1961) belongs to the first group. This group advocated the development of a traditional city with medium and high-density buildings, blocks around the perimeter, walking, and mixed-use. Similarly, Whyte (1988) praised streets with high pedestrian and walking opportunities and argued that barely visible urban details such as shop windows, stairs, and doorways were indispensable for city life. Gehl (2013) is also a supporter of mixed-use pedestrian streets and active suburbs (i.e., block facades), which he believes can promote social interaction and stimulate commercial activity. Instead, Corbusier (1947) proposed a municipality based on superblocks (i.e., large urban neighborhoods) separated by multi-lane highways and apartment buildings set aside from sidewalks and located in the open space. Similarly, Hilberseimer (1944) maintained a concentrated city form and proposed plans that included highway networks and the same high-rise residential neighborhoods aligned with them.

Various domestic scientists, including V. Huk, who considered the main principles of urban transport planning, S. Diak and O. Musiezdov, who deal with historical aspects of 
urbanization of the city, V. Mironenko, who discovered the ergonomic features of urban design, Ye. Sarapina, who studies the processes of renewal and spatial transformation of the city, V. Timinsky and S. Shlipchenko, who compare the city with the body and research the possibilities of different cities of Ukraine and urban studies, I. Tishchenko, who is of scientific interest in the evolution of the understanding of public space, V. Shimko, who developed the design of the urban environment, and others, deal with the problem of urban planning. Despite many works on urban planning, there is no clear definition of the socio-economic model of urban development in the country and a sufficient understanding of the problems of its formation.

The purpose and problem of research. This article provides a study of current issues of formation of a socio-economic model of urban development, as the socio-economic side of the problem involves the analysis of the complex system structure of the organization of urban space. This structure is the object of investment and is located within the urban areas, the development of which should be carried out following the principles, objectives, and limitations of innovation and social policy of the state.

The results of the research. The development of scientific and technological progress and industrialization in the late 19th - early 20th centuries led to a sharp increase in population concentration and the progress of economic activity in cities. The urban population growth in the middle of the 20th century increased attention to the social component of the city. Urbanization began to be interpreted as a process of high concentration and integration of human activities, including the deployment of productive forces, resettlement.

At present, in the competition for attracting resources and investments, Ukrainian cities are inferior to European cities in terms of number and level of development. This is partly because Ukrainian city administrations still have a relatively low level of information openness and lack of a systematic approach to external positioning and branding of cities, building effective communication strategies with stakeholders.

Modern conditions determine the dynamic nature of the city's development, which absorbs different resources. The structure of such resources is variable and depends not only on the structure of the needs of the urban environment's subjects but also on the results of innovative and intellectual development (Sarchenko, 2015). In addition, external challenges and threats posed by the national and global economy affect the structure of urban resource consumption. In 
the process of resource transformation, results are achieved, which can be subsequently adjusted depending on the degree of achievement of urban development goals.

The general structural transformations of societies strongly influence the municipal development processes. In 1990-2000, societies witnessed unprecedented changes in recent history: the destruction of political and economic scenarios, new integration approaches, globalization of the economy and the downfall of national policies, mass migration, government downsizing, and social restructuring. For megacities in developing countries, problems arise because of their ever-growing population.

Structural changes in societies are evident in urban areas. Urban geography analyzes the complex aspects of urban social, economic, cultural, and political processes, models, structures, and urban planning processes to create or maintain local comparative advantages. Therefore, the economic model is a necessary component of urban planning, working to identify potential cities growth areas. Properly implemented, these growth directions will allow the city to achieve better financial prosperity, ensuring that the city itself will be more attractive to companies that want to expand. Economic development is essential for any city that wants to grow.

Extensive and intensive development paths characterize urbanization. Agrarian countries in the past are experiencing an extensive course of urbanization, when the growth of cities and the formation of urban structures depends primarily on the needs of material production and, in particular, extensive expansion of industrial base through the construction of new factories and plants, development of new mineral deposits. Given the rapid extension of the urban population and the emergence of many new cities, the concentration of non-agricultural functions mainly in cities, the predominance of the general increase in urban population - people from rural areas, this type of urbanization affects the cultural, educational, and qualification level of labor resources, the structure of needs and public services (Al-Fahad, 2016).

The intensive type of urbanization involves improving the socio-economic development of existing cities, forming their network under the country's needs. In this way, there is a transition to a multifunctional basis for urban development, which is manifested in the complexity of the structure and expansion of urban functions. Integrated urban development, growth of their economic and socio-cultural potential, rural urbanization, multilateral mobility, changing sources of urban population growth, increasing the number of large cities and increasing the concentration of population, the formation of urban agglomerations, urban and 
rural settlements are features of the current stage of urbanization (Al-Fahad, 2016). It is developing through the qualitative improvement and further transformation of urban settlements, the complexity of the forms and systems of urban structures within the territories covered by cities.

Urbanization improves the quality of life of the population, but at the same time, creates demographic, socio-economic, environmental, and even urban problems in the city. Such problems include changes in the demographic structure of both the employed population and the general population, increased migration, social stratification of the city, the need to attract additional investment in the city's economy, changes in demand and prices for residential real estate, imperfections in engineering, energy, transport, telecommunications, and social infrastructure. The latter are often designed without considering population growth, pollution of the atmosphere, water sources, the soil of the urban area, uneven development and rupture of the city, the spread of infectious diseases, and others. It should be noted that the issue of sustainable socio-economic development of cities has to be addressed in the face of chronic budget deficits. Therefore, the analysis and forecasting of integrated socio-economic development of the city should be critical strategic components of its management.

Efforts to revitalize cities will not succeed without the significant contribution of community members. Business owners and locals will always have useful information to help make good changes and updates for the city. Other forms of urban planning may need to be used during activation. For example, environmental planning may be necessary to clean up leftovers from the previous land uses. The socio-economic model refers to the ability of community members to understand economic and social concerns and resolve difficulties through social collaboration. The socio-economic model clarifies the reasons for countries encountering comparable social issues and reveals various aspects of confounding them (The Institute for Social Development and Policy Research, 2015).

An additional problem is the lack of capacity in public institutions to manage urbanization. Infrastructure planning should be seen as a critical element in strategic spatial planning based on understanding the main strengths, namely knowledge of the economic base, among others (United Nations Human Settlements Program, 2009). Socio-economic parameters can serve as indicators for urban supply and recycling infrastructure planning. Understanding education and the economic situation are essential for household waste production in different 
regions. More precisely, household income and expenditure are closely correlated with solid waste generation (Warth et al., 2020). In a review article, Jones et al. (2015) show the impact of socio-economic criteria on electricity consumption with the main factor of household income.

Given the projected sharp increase in urbanization worldwide (Seto et al., 2012), the management and optimization of urban ecosystem services, i.e., green areas in urban areas such as gardens, parks, street trees, and other natural sites, are critical for the social and ecological essence of the city development model. Socio-economic factors in cities affect ecosystem services that provide biodiversity and ecosystem processes in two different and interrelated ways, first, by influencing the management of urban green spaces and, in turn, the supply of ecosystem services (Pickett et al., 2008). Second, they impact by changing human needs and activities and, consequently, human demand for specific ecosystem services (Luck et al., 2009). For certain services, there is an indirect way in which the socio-economic status of a resident can affect how the provision of ecosystem services affects his or her well-being (i.e., his or her physical or mental health).

In general, the formation of a particular living environment, which includes the necessary public services, can be called more simply - social infrastructure. Social infrastructure occupies a substantial part in the nation's economic development and the development of society's quality of life. It enhances social well-being and promotes economic growth by providing services that enable businesses to grow and prosper. Social infrastructure is a set of industries and enterprises that functionally ensure the normal life of the population (Bogun, 2013). These include housing, its construction, socio-cultural facilities, the entire sphere of housing and communal services, enterprises and organizations of health care, education, preschool education; companies and organizations related to recreation and leisure; retail trade, public catering, services, sports, and health facilities; passenger transport and communication services; system of institutions that provide services of legal and financial-credit nature (legal advice, notaries, savings banks, banks), etc.

Social infrastructure is provided in response to citizens' basic needs. It improves the quality of life, stability, and social well-being and acts as a building block for increasing human and social capital. Like any dynamically developing socio-economic system, the city has many critical states. The latter is characterized by weakening of the quality of development and degradation, losses in the rate of capitalization of urban assets resulting from degradation, and 
deviations of the achieved results from the set goals. The potential of urban development, which varies depending on external circumstances and the effectiveness of the urban economy, must be characterized by a specific area of acceptable values, which set allowable limits for the decline in the capitalization of urban assets (Sarchenko, 2015). The city authorities determine the latter based on public opinion. The limit of the permissibility of reducing the pace and level of capitalization, their economic essence is determined by the ability and willingness to postpone the satisfaction of some needs, which means delays in obtaining some results.

Moreover, the socio-economic model of urban development is influenced by information and communication technologies, which will play an increasingly important role in urban governance and everyday urban life's social and economic processes. In the medium to long term, the city's infrastructure will be based on the so-called digital shell, which comprises billions of sensors for data collection, network nodes, communication devices, and data control and analysis posts related to servers. Such a digital envelope of the city will create connections between all its stakeholders (entities involved in urban development), including various groups, businesses, non-profit organizations, public authorities, and local governments (Rabari \& Storper, 2015).

This approach to urban governance essentially involves the active involvement and participation of the urban population in urban development. It is about the growing role of local information technology platforms, which provide mass participation in strategically important decisions to involve citizens in governance. Of course, the level of openness of public institutions is growing, access to information and feedback services is expanding. Citywide services become more interactive not only by providing information about events in city life but also by enabling users (individuals, organizations, communities) to communicate with each other and with representatives of the city authorities and deputies, ensuring openness, readiness for dialogue, and focus on constructive collaboration (O'Sullivan, 2012). Forms of such communication can range from comments, discussions in forums or blogs to personal communication and more. The information collected by numerous sensors (visual, sound, motion, water, heat and gas analyzers, etc.) is aggregated into databases and plotted on a digital map. This makes it possible to have a digital view of the city in the form of a set of maps and graphs and track them online. As a result, managerial decisions are made possible through qualitative and quantitative analysis, making them much more effective and less dependent on subjectivity. 
Of course, involving citizens in managing urban processes is not a new idea, but modern digital technologies and social media allow implementing this idea fully. The openness of urban development data will make it difficult for local administrations to hide problems or manipulate statistics. Social media will draw the attention of the urban community to essential issues, involve various stakeholders in a constructive dialogue, create an experience of cooperation and compromise solutions.

Other aspects that hinder the effective integrated development of urban areas and the formation of a socio-economic model of urban development include the lack of information needed to make decisions on project entry, planning, and management of project development, lack of advanced infrastructure development, and coordination between urban executive power and private business, as well as untimely adjustment of the regulatory framework (Al-Fahad, 2016). These factors can be attributed to the information, organizational, economic, and regulatory groups. The obtained grouping of factors allows determining the main directions of work on the preparation and substantiation of methodological provisions and practical recommendations for improving the efficiency of integrated development of territories.

Conclusions. The effectiveness of municipal governments determines the success of the city development strategy. Municipal governments should be focused on creating the necessary conditions and implementing specific measures to achieve strategic goals, taking into account the impact of information and communication technologies, strengthening urbanization, structural changes in society, and social infrastructure. The imperative of strategic planning, which determines the prospects for developing urban areas, is the concept of socio-economic development of the city. According to this concept, first, the strategy itself and its target unit are set. The next step determines the private strategies, resource provision, and the general direction of socio-economic policy. The conceptual framework for implementing the strategy is developed.

Thus, the concept in its final form contains elements of the mechanism for implementing the city's self-development strategy. Then such a concept is considered and approved by the city government, thus solving the city's integrated development, management decisions are made, and justified strategic choices. It should also be noted that the concept as a document has a framework character and provides for further specification of the actions of the city authorities based on a program-target approach, namely the development of a municipal program of integrated socioeconomic development of the city. Such a program is of a directive nature, as it may provide for 
measures, the need for which is provided by resolutions and decrees of public authorities and local governments. Acting as one of the main elements of the new governance mechanism, the program promotes the effective combination of state and territorial interests in solving problems of territorial development.

\section{References}

Al-Fahad, A.Z. (2016). Concepts of development of urban areas in developing countries. Vestnik Universiteta, 11, 12-17.

Bogun, K.V. (2013). The role of social infrastructure in the formation of a positive image of the city. Effective Economy. Retrieved December 15, 2021, from http://www.economy.nayka.com.ua/?op=1\&z=1891.

Corbusier, L. (1947) The city of tomorrow and its planning. London: Architectural Press.

Gehl, J. (2013). Cities for people. Washington: Island press.

Hilberseimer, L. (1944). The new city: principles of planning. Chicago: Theobald.

Jacobs, J. (1961). The life and death of great American cities. New York: Random House.

Jones, R.V., Fuertes, A., \& Lomas, K.J. (2015). The socio-economic, dwelling and appliance related factors affecting electricity consumption in domestic buildings. Renewable and Sustainable Energy Reviews, 43, 901-917.

Luck, G.W., Chang, K.M.A., \& Fay, J.P. (2009). Protecting ecosystem services and biodiversity in the world's watersheds. Conservation Letters, 2, 179-188.

O’Sullivan, A. (2012). Urban economics. 8th ed. New York: McGraw-Hill/Irwin.

Pickett, S.T.A., Cadenasso, M.L., Grove, J.M., Groffman, P.M., Band, L.E., Boone, C.G., Burch Jr, W.R., Grimmond, S.B., Hom, J., Jenkins, J.C., Law, N.L., Nilon, C.H., Pouyat, R.V., Szlavecz, K., Warren, P.S., \& Wilson, M.A. (2008). Beyond urban legends: An emerging framework of urban ecology, as illustrated by the Baltimore Ecosystem Study. BioScience, 58, 139-150.

Rabari, C. \& Storper, M. (2015). The digital skin of cities: Urban theory and research in the age of the sensored and metered city, ubiquitous computing and Big Data. Cambridge Journal of Regions, Economy and Society, 8(1), 27-42.

Sarchenko, V.I. (2015). Modeling modern city development under conditions of target mobility and uncertainty. Proceedings of Irkutsk State Technical University, 6(101), 266-271. 
Seto, K.C., Güneralp, B. \& Hutyra, L.R. (2012). Global forecasts of urban expansion to 2030 and direct impacts on biodiversity and carbon pools. Proceedings of the National Academy of Sciences, 109, 16083-16088.

The Institute for Social Development and Policy Research (2015). Comparative studies of social-economic models. Retrieved December 15, 2021, from http://isdpr.org/en/achievements/04.

United Nations Human Settlements Programme. (2009). Planning sustainable cities: Global report on human settlements. Retrieved December 15, 2021, from https://unhabitat.org/sites/default/files/download-manager-

files/Global\%20Report \%20on \% 20Human \% 20Settlements\%202009\% 20Planning\%20Sust ainable \% 20Cities.pdf.

Warth, G., Braun, A., Assmann, O., Fleckenstein, K., \& Hochschild, V. (2020). Prediction of socio-economic indicators for urban planning using VHR satellite imagery and spatial analysis. Remote Sens, 12(11), 1730. https://doi.org/10.3390/rs12111730.

Whyte, W.H. (1988). City: Rediscovering its center. New York: Doubleday. 